\title{
Mr 40000 human colonic epithelial protein expression in colonic mucosa and presence of circulating anti-Mr 40000 antibodies in cotton top tamarins with spontaneous colitis
}

\author{
K M Das, M Vecchi, L Squillante, A Dasgupta, $M$ Henke, N Clapp
}

\begin{abstract}
Saguinus oedipus, Callithrix jacchus, and Saguinus fuscicollis are three species of New World monkeys which develop a form of colitis that is similar to human ulcerative colitis. Only $S$ oedipus, however, develop colon cancer. We examined intestinal tissues from these animals for the presence of an antigen cross reacting to the Mr $\mathbf{4 0 0 0 0}$ human colonic epithelial protein that acts as an autoantigen in ulcerative colitis. Using an anti-Mr $\mathbf{4 0} 000$ monoclonal antibody $\left(7 \mathrm{E}_{12} \mathrm{H}_{12}\right.$, IgM isotype), by an immunoperoxidase assay we showed that all colon specimens from $S$ oedipus reacted with $7 \mathrm{E}_{12} \mathrm{H}_{12}$; however, the colonic tissue from $C$ jacchus and $S$ fuscicollis did not. In immunotransblot analysis eluted IgG antibody bound to human ulcerative colitis colon (CCA-IgG) reacted with $M r 40000$ protein(s) present in the extracts of colon from $S$ oedipus animals and humans. Small intestinal tissue reacted neither with $7 \mathrm{E}_{12} \mathrm{H}_{12}$ nor with CCA-IgG. In $\mathrm{S}$ oedipus, the $\mathrm{Mr} \mathbf{4 0 0 0 0}$ protein was localised exclusively to colonic epithelial cells. Preincubation of seven $S$ oedipus colon specimens with eight of 10 sera from animals with acute or chronic colitis and 0 of four sera from animals without colitis almost completely inhibited the binding of $7 E_{12} H_{12}$ to the colonic epithelium. Four of these 10 sera inhibited the binding of $7 \mathrm{E}_{12} \mathrm{H}_{12}$ to the autologous colon. These results show the presence of circulating autoantibodies in $S$ oedipus with colitis against an epitope(s) on Mr 40000 protein shared by human and $S$ oedipus colon.
\end{abstract}

The study of ulcerative colitis has been greatly hampered by the lack of a suitable experimental animal model for the disease. In recent years the development of spontaneous colitis and superimposed colonic cancer have been described in one species of South American primates (Saguinus oedipus, cotton top tamarin). ${ }^{1-3}$ Interestingly, two other species from the Callitrichidae family (Callithrix jacchus and Saguinus fuscicollis) also show a similar colitis but have never been reported to develop colon cancer. ${ }^{2+5}$ The colitis which apparently develops during the first year or so of life is usually of noninfectious origin, ${ }^{3}$ chronic, and can show acute exacerbations. ${ }^{+}$Other similarities to human ulcerative colitis have been observed in studies of $S$ oedipus colitis regarding histological features, ${ }^{267}$ mucin biochemistry, ${ }^{8}$ and lectin histochemistry. ${ }^{911}$ The mechanisms which cause the development of colitis in tamarins are unknown.

We recently described an $\mathrm{Mr} 40000$ protein in human colon that is specifically recognised by colon bound IgG from patients with ulcerative colitis, called CCA-IgG, and not by tissue bound IgG extracted from Crohn's disease affected colon and normal IgG. ${ }^{12}{ }^{13} \mathrm{The} \mathrm{Mr} 40000$ protein is also recognised by autologous $C C A-\operatorname{IgG}^{13}$ and ulcerative colitis serum IgG. ${ }^{14}$ is These data suggest that the $\mathrm{Mr} \mathbf{4 0 0 0 0}$ colonic protein acts as an autoantigen(s) in ulcerative colitis. ${ }^{13-15}$ The protein has been purified from human colon and murine monoclonal antibodies have been developed. ${ }^{1617}$ By using one of these monoclonal antibodies the protein has been localised exclusively to human colonic epithelial cells mainly along the basolateral and apical domains of plasma membrane. ${ }^{16}$

Because of the similarities observed between tamarin and human colitis, we examined the cross reactivity of the $\mathrm{Mr} \mathbf{4 0 0 0 0}$ human colonic protein to tamarin colon tissue by the immunoperoxidase method using an anti-Mr 40000 monoclonal antibody. The presence of circulating anti-Mr 40000 antibodies in tamarins with colitis was investigated by an inhibition immunoperoxidase assay. The immunoreactive antigen(s) in tamarin colon is further analysed by immunotransblot analysis using CCA-IgG extracted from human ulcerative colitis colon.

\section{Methods}

All tamarins and marmosets were from the colony housed at the Marmoset Research Center, Oak Ridge Associated Universities, Oak Ridge, Tennessee.

\section{TISSUE SPECIMENS}

A total of 66 intestinal tissue specimens from colon (56 specimens) and small bowel (10 specimens) from $24 S$ oedipus (cotton top tamarin), 10 $S$ fuscicollis (saddle back tamarins), and nine $C$ jacchus (common marmosets) were used for immunoperoxidase experiments. The colonic specimens consisted of multiple samples from right and left colon. The specimens had been obtained at Oak Ridge Associated Universities ${ }^{18}$ during endoscopy or at necropsy, fixed in formalin, and embedded in paraffin. Specimens were coded and sent to the Robert Wood Johnson Medical School for the immunoperoxidase assay. Histological interpretations of the specimens were made at Oak Ridge. Tissue 

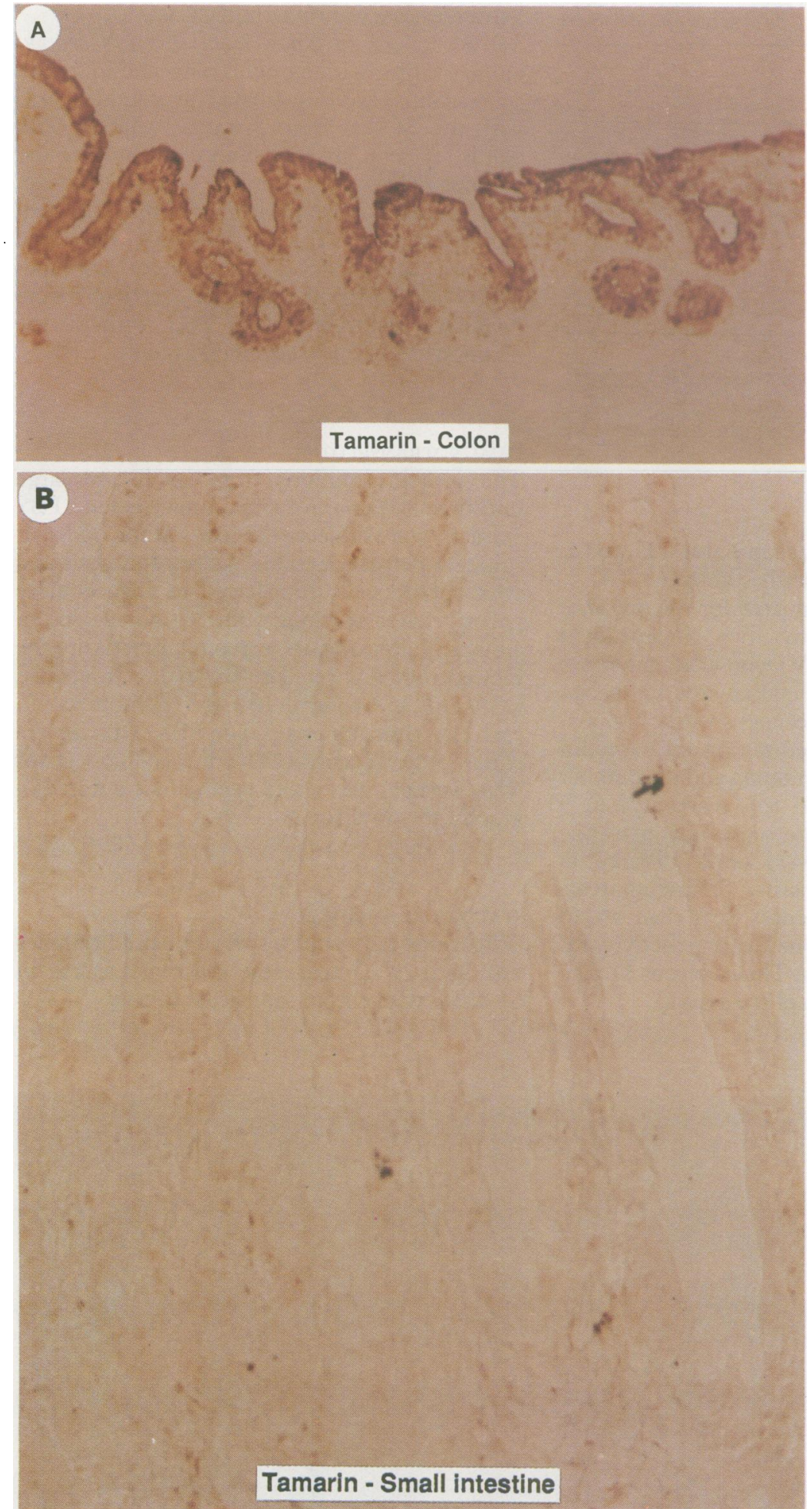

Figure 1: Saguinus oedipus colon from animal with chronic colitis (immunoperoxidase, original magnification $\times 10$ ). (A) Immunoreactivity of $7 E_{12} H_{12}$ on tamarin colon. The reactivity is localised only to colonic epithelial cells in the crypts and along the luminal surface. (B) Small intestinal specimen from a tamarin when examined with $7 E_{12} H_{12}$ monoclonal antibody. No immunoreactivity is seen.

specimens with acute inflammation consisting of mucosal ulcerations, infiltration with polymorphonuclear cells and lymphocytes in the mucosa, and crypt abscess were considered as acute colitis. Chronic colitis was defined as colonic mucosa showing excess inflammatory cellular infiltrates without much epithelial cell destruction.

For immunotransblot experiments, segments of small bowel and colon obtained from two cotton top tamarins at necropsy were sent. These specimens were prepared following the method previously reported for human colon. ${ }^{13}$ Briefly, specimens were minced, washed in phosphate buffered saline (PBS) containing $2 \mathrm{mmol} / \mathrm{l}$ ethylenediamine tetra-acetic acid and $2 \mathrm{mmol} / \mathrm{l}$ sodium azide and homogenised with a Polytron. After adding phenylmethylsulphonyl fluoride to a final concentration of $2 \mathrm{mmol} / \mathrm{l}$, the samples were centrifuged at $2000 \mathrm{~g}$ for 30 minutes and at $20000 \mathrm{~g}$ for 60 minutes. The resulting protein solution (PBS extract) was used for immunotransblot analysis.

\section{ANTIBODIES}

The anti-Mr 40000 monoclonal antibody $\left(7 \mathrm{E}_{12} \mathrm{H}_{12}, \mathrm{IgM}\right.$ isotype) and an unrelated murine monoclonal antibody of $\operatorname{IgM}$ isotype were used in immunoperoxidase experiments. The production and characterisation of the anti-Mr 40000 monoclonal antibody have been reported previously. ${ }^{16}$ For the immunotransblot experiments, tissue bound IgG eluted from two ulcerative colitis colon specimens were used. Colon tissue bound IgG were obtained according to the method previously described. ${ }^{13}$ Colon tissue eluted IgG from a patient with Crohn's colitis and purified normal serum IgG were used as control.

\section{SERA FROM TAMARINS}

Fourteen coded sera from cotton top tamarins (S oedipus) were sent from Oak Ridge primate centre for the inhibition-immunoperoxidase assay as described below. These included six sera from cotton top tamarins with clinical and histological evidence of acute colitis, four with chronic colitis, and four without colitis.

\section{IMMUNOPEROXIDASE METHOD}

Two $5 \mu \mathrm{m}$ thick serial sections from each specimen were deparaffinised and rehydrated in decreasing concentrations of ethyl alcohol. The sections were incubated in $\mathrm{PBS}, \mathrm{pH} 7 \cdot 4$, containing $0.3 \% \mathrm{H}_{2} \mathrm{O}_{2}$ for 30 minutes to block the endogenous peroxidase activity and in $1 \%$ normal horse serum for two hours to block nonspecific binding of the second antibody to the section. Either anti-Mr 40000 monoclonal antibody or control monoclonal antibody was then added to the sections and incubated overnight. The sections were successively incubated with biotinylated goat antimouse $\operatorname{IgM}$ for 60 minutes and with avidin-biotin-peroxidase complex for 90 minutes. 3-3' diaminobenzidine was then added to show the immune reaction. All the incubations were done at room temperature except for the overnight incubation which was performed at $4^{\circ} \mathrm{C}$. Extensive washings in PBS, pH 7.4, were done between each incubation. After dehydration and mounting the slides were observed under a light microscope.

To examine the reactivity of $7 \mathrm{E}_{12} \mathrm{H}_{12}$ against carbohydrate moiety, we treated parallel tissue sections with neuraminidase (Sigma) $(0 \cdot 1 \mathrm{unit} /$ section) and periodate $(0.1 \mathrm{~mol} / \mathrm{l}$ solution) before incubation with the monoclonal antibody, 
TABLE I Results of immunoperoxidase experiments with $7 E_{12} H_{12}$ on tamarin intestinal tissues

\begin{tabular}{|c|c|c|c|c|c|}
\hline & $\begin{array}{l}\text { No of } \\
\text { animals }\end{array}$ & $\begin{array}{l}\text { Sex } \\
(M / F)\end{array}$ & $\begin{array}{l}\text { Mean age } \\
(y r s) \text { (range) }\end{array}$ & $\begin{array}{l}\text { No of } \\
\text { specimens } \\
\text { (colon })^{\star}\end{array}$ & $\begin{array}{l}\text { Mean }(S D) \\
\text { reactivity } \\
\text { scoret }\end{array}$ \\
\hline \multicolumn{6}{|l|}{ Saguinus oedipus: } \\
\hline Chronic colitis & $10 \ddagger$ & $4 / 6$ & $7 \cdot 2(0.4-9 \cdot 7)$ & 16 & $1.94(0.82)$ \\
\hline Acute colitis & $13 \ddagger$ & $6 / 7$ & $8 \cdot 0(0 \cdot 4-12 \cdot 2)$ & 19 & $1.37(0.68)$ \\
\hline Normal colon & 1 & 1 & $0 \cdot 1$ & 1 & \\
\hline \multicolumn{6}{|l|}{ Saguinus fuscicollis: } \\
\hline Chronic colitis & 9 & $3 / 6$ & $8 \cdot 7(2 \cdot 5-14 \cdot 5)$ & 9 & 0 \\
\hline Normal colon & 1 & 1 & $9 \cdot 1$ & 1 & 0 \\
\hline \multicolumn{6}{|l|}{ Callithrix jacchus: } \\
\hline Chronic colitis & 10 & $5 / 5$ & $6 \cdot 2(0 \cdot 1-14 \cdot 3)$ & 10 & $0 \|$ \\
\hline
\end{tabular}

$\star$ None of the small intestinal specimens from 10 animals reacted with $7 \mathrm{E}_{12} \mathrm{H}_{12}$.

$\dagger$ Expressed as the mean of individual scores $(0$ to $3+)$ ranked by two observers (see text) without the knowledge of histological interpretation and the species of animals.

$\ddagger$ Two animals with chronic colitis and one with acute colitis had colon cancer.

SAll colon specimens from $S$ oedipus species were positive with some variations in the intensity $(1+$ to $3+) ; p<0 \cdot 05$ chronic colitis $v$ acute colitis.

||Several deep glands were positive only in two of the 10 specimens.

$7 \mathrm{E}_{12} \mathrm{H}_{12}$. Subsequent procedure was followed as monoclonal antibody described above.

All the slides were evaluated for the presence of immunoreactivity by two independent observers (KMD and MV) who were not aware of the histological interpretation and the species from which the tissue specimens were obtained. The reactivity was graded taking into account both the intensity of the staining and the number of reactive cells from 0 (no reactivity) to 3 (maximal reactivity). The scores given by the two independent observers never differed in terms of presence or absence of immunoreactivity. Occasional differences (less than $5 \%$ of specimens) consisted of one level of reactivity for a few positive specimens. The code was broken (by NC) after completion of the assays.

\section{INHIBITION IMMUNOPEROXIDASE ASSAY}

Serial sections of colon from seven $S$ oedipus animals (three with chronic colitis and four with acute colitis) were incubated overnight at $4^{\circ} \mathrm{C}$ with the 14 sera from $S$ oedipus animals with colitis (10 sera: six acute and four chronic) and without colitis (four sera) as described above. The sections were washed in PBS and then incubated with $7 \mathrm{E}_{12} \mathrm{H}_{12}$ following the same protocol as described above under immunoperoxidase method. Parallel sections were incubated overnight with PBS without the addition of $S$ oedipus serum followed by $7 \mathrm{E}_{12} \mathrm{H}_{12}$.

\section{IMMUNOTRANSBLOT}

The protein solutions from small and large intestine of tamarins and human colon (PBS extracts) were subjected to $10 \%$ sodium dodecylsulphate-polyacrylamide gel electrophoresis and electrophoretically transferred to nitrocellulose paper. ${ }^{13}$ After blocking with $5 \%$ bovine serum albumin for two hours at room temperature the blotted proteins were probed with ${ }^{125} \mathrm{I}$-labelled CCA-IgG and control IgG for 60 minutes. In each experiment human colon PBS extracts were run as positive control. The nitrocellulose strips were washed, dried, and exposed for autoradiography at $-80^{\circ} \mathrm{C}$ for 24 hours.

\section{STATISTICAL ANALYSIS}

Wilcoxon's rank sum test for unpaired samples was used to compare the reactivity scores in $S$ oedipus with chronic and acute colitis.

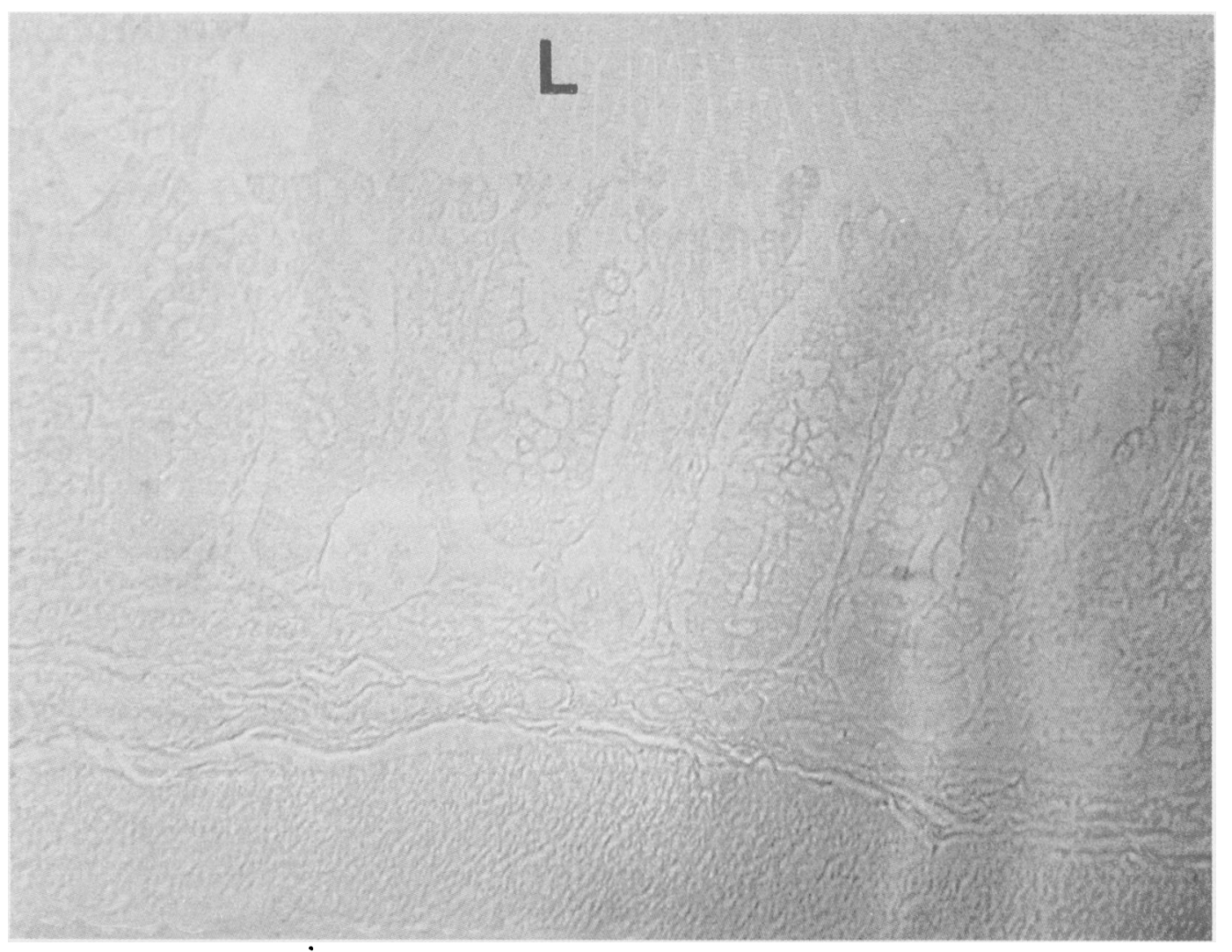




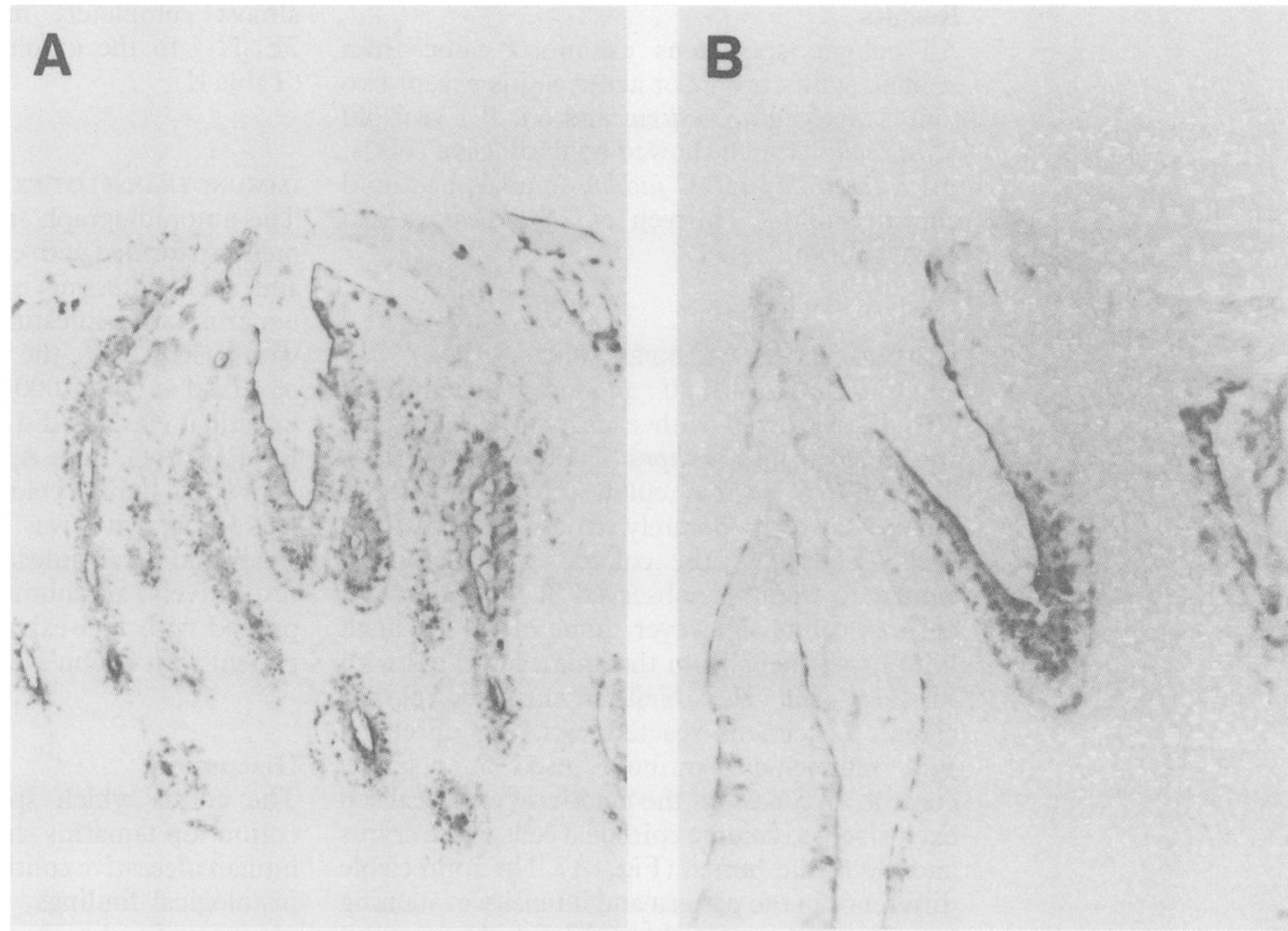

Figure 3: Saguinus oedipus colon from an animal with acute colitis (immunoperoxidase, original magnifications $\times 10$ in $(A)$ and $\times 40$ in $(B))$. Reduction of $7 E_{12} H_{12}$ immunoreactivity with 'patchy' pattern is evident when compared with Figure $1 A$.

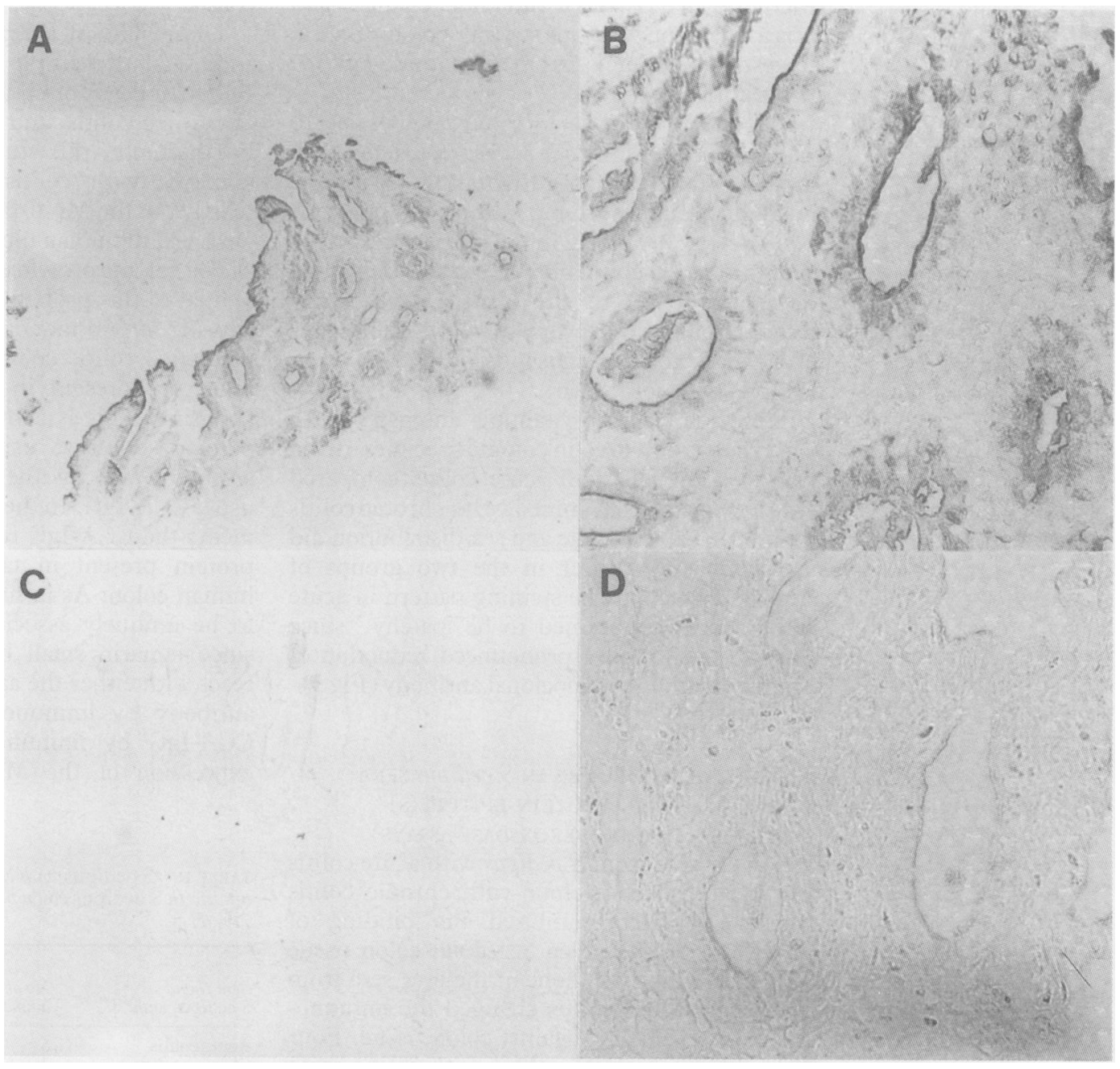

Figure 4: Saguinus oedipus colon from an animal with acute colitis (immunoperoxidase, original magnifications $\times 10$ in $(A)$ and $(C)$ and $\times 40$ in $(B)$ and $(D))$. Immunoreactivity of $7 E_{12} H_{12}$ against the colonic epithelium $(A \mathcal{E} B)$ is completely blocked by preincubation of the serial sections of the same colon specimen $(C \mathcal{G} D)$ with serum from an $\mathrm{S}$ oedipus animal with acute colitis, suggesting the presence of circulating antibody against the shared epitope reactive to $7 E_{12} H_{12}$. 


\section{Results}

All colonic specimens examined came from animals with chronic or acute colitis except two (one 5 week old $S$ oedipus and one $9 \cdot 1$ year old $S$ fuscicollis) which showed no findings of colitis. All $S$ fuscicollis and $C$ jacchus animals had mild chronic colitis. Thirteen of $24 S$ oedipus had acute colitis (Table I).

\section{IMMUNOPEROXIDASE EXPERIMENTS}

The anti-Mr 40000 monoclonal antibody $\left(7 \mathrm{E}_{12} \mathrm{H}_{12}\right)$ reacted with each of the 36 colonic specimens from $S$ oedipus (Table I and Fig 1A). The only $S$ oedipus colon specimen without colitis showed moderately strong reactivity $(2+)$ with $7 \mathrm{E}_{12} \mathrm{H}_{12}$ in the colonic epithelial cells, similar to what was observed in $S$ oedipus with chronic colitis. However, none of the 10 small bowel specimens from the animals reacted with $7 \mathrm{E}_{12} \mathrm{H}_{12}$ (Fig 1B). Neither small bowel nor colonic specimens reacted with the unrelated IgM monoclonal antibody used as negative control. In $S$ oedipus the reactivity was localised exclusively to colonic epithelial cells in the crypts and along the lumen (Fig 1A). No appreciable difference in the pattern and intensity of staining was seen between right and left colonic specimens except in a few animals. After treatment with neuraminidase and periodate, the immunoreactivity of $7 \mathrm{E}_{12} \mathrm{H}_{12}$ did not change and increased somewhat in several colon tissues, suggesting a better access to the peptide-epitope by the antibody.

In contrast to $S$ oedipus colon none of the 10 colonic specimens from $S$ fuscicollis reacted with $7 \mathrm{E}_{12} \mathrm{H}_{12}$ (Table I, Fig 2). Eight of the 10 colonic mucosal specimens from $C$ jacchus did not react with $7 \mathrm{E}_{12} \mathrm{H}_{12}$ (Table I). In the remaining two the colonic mucosal epithelium lining the lumen and the glands close to the lumen were totally negative. However, several glands at the deeper level close to the muscularis mucosa were positive (data not shown)

Reduction in the staining intensity with $7 \mathrm{E}_{12} \mathrm{H}_{12}$ was observed in colonic specimens from $S$ oedipus animals with acute colitis compared with specimens from animals with chronic colitis $(p<0.05)$ (Table I). Age and sex distribution did not significantly differ in the two groups of animals (Table I). The staining pattern in acute colitis specimens seemed to be 'patchy,' since some areas showed a pronounced reduction of reactivity with the monoclonal antibody (Fig 3).

PRESENCE OF ANTIBODIES IN $S$ oedipus SERA AGAINST Mr 40000 PROTEIN-EPITOPE(S) (INHIBITION IMMUNOPEROXIDASE ASSAYS) Five of six sera from $S$ oedipus with acute colitis (Fig 4) and three of four with chronic colitis almost completely inhibited the binding of $7 \mathrm{E}_{12} \mathrm{H}_{12}$ to all the seven $S$ oedipus colon tissue (Table II). However, none of the four sera from $S$ oedipus without colitis changed the immunoreactivity of $7 \mathrm{E}_{12} \mathrm{H}_{12}$ against colon tissue. Four of the 10 sera from $S$ oedipus with colitis came from the same four animals whose colon tissues were among the seven used for the inhibition immunoperoxidase assay. These four sera also almost completely inhibited the binding of $7 \mathrm{E}_{12} \mathrm{H}_{12}$ to the autologous colonic epithelium (Table II).

\section{MMUNOTRANSBLOT EXPERIMENTS}

The autoradiograph from the transblot experiment performed with extracts from tamarin large and small intestine is shown in Fig 5. When tamarin large intestinal extracts were probed with CCA-IgG the immunoreactivity was observed at Mr 40000 (lane A2). Tamarin small intestinal extracts did not react with the CCAIgG (lane A1). Lane A3 shows reactivity of CCAIgG with a human colon extract.

No reactivity was observed when tamarin small and large intestinal extracts $\left(B_{1}\right.$ and $B_{2}$ respectively) and human colon extract $\left(B_{3}\right)$ were probed with IgG extracted from the colon of a patient with Crohn's disease of the colon.

\section{Discussion}

The colitis which spontaneously develops in cotton top tamarins shares several features with human ulcerative colitis. The clinical course, the histological findings, the reduction in specific glycoprotein classes, and the pattern of lectin histochemistry reported in tamarin colitis are strikingly similar to those observed in human colitis. ${ }^{2-46-9}$

The results of the present study indicate an additional structural similarity between the colonic mucosa of cotton top tamarins, a model of chronic colitis, and human ulcerative colitis. Furthermore, this study shows that sera from tamarins with colitis contain autoantibodies reactive to the $\mathrm{Mr} 40000$ protein-epitope as also observed in human ulcerative colitis. ${ }^{13+4}$ The $\mathrm{Mr}$ 40000 colonic protein or cross reactive epitope(s) related to this protein, which are recognised by anti-Mr 40000 monoclonal antibody as well as ulcerative colitis colon eluted antibody (CCAIgG), are present in the colonic tissue from tamarins. This is shown both by an immunoperoxidase assay, using $7 \mathrm{E}_{12} \mathrm{H}_{12}$ monoclonal antibody and by the immunotransblot study using CCA-IgG. In the immunotransblot experiments the CCA-IgG reacted with an $\mathrm{Mr} 40000$ protein present in tamarin colon as well as human colon. As in humans, the protein seems to be uniquely associated with colonic tissue, since tamarin small bowel specimens did not react with either the anti-Mr 40000 monoclonal antibody by immunoperoxidase assay or the CCA-IgG by immunotransblot analysis. The expression of the $\mathrm{Mr} 40000$ protein in the

TABLE II S oedipus with colitis have serum antibodies that bind with $\mathrm{S}$ oedipus colon blocking the immunoreactivity of $7 E_{12} H_{12}$

\begin{tabular}{|c|c|c|}
\hline $\begin{array}{l}\text { Sera from } \\
\text { S oedipus with: }\end{array}$ & $\begin{array}{l}\text { No of } \\
\text { animals }\end{array}$ & $\begin{array}{l}\text { No of sera that blocked the } \\
\text { binding of } 7 E_{12} H_{12} \text { to } \\
\text { S oedipus colon tissue }\end{array}$ \\
\hline $\begin{array}{l}\text { Acute colitis } \\
\text { Chronic colitis }\end{array}$ & $\begin{array}{l}6 \\
4\end{array}$ & $\left.\begin{array}{l}5^{\star} \\
3^{\star}\end{array}\right\} 80 \%$ \\
\hline
\end{tabular}

^Two sera in each group inhibited the binding of $7 \mathrm{E}_{12} \mathrm{H}_{12}$ to autologous colon tissue. 


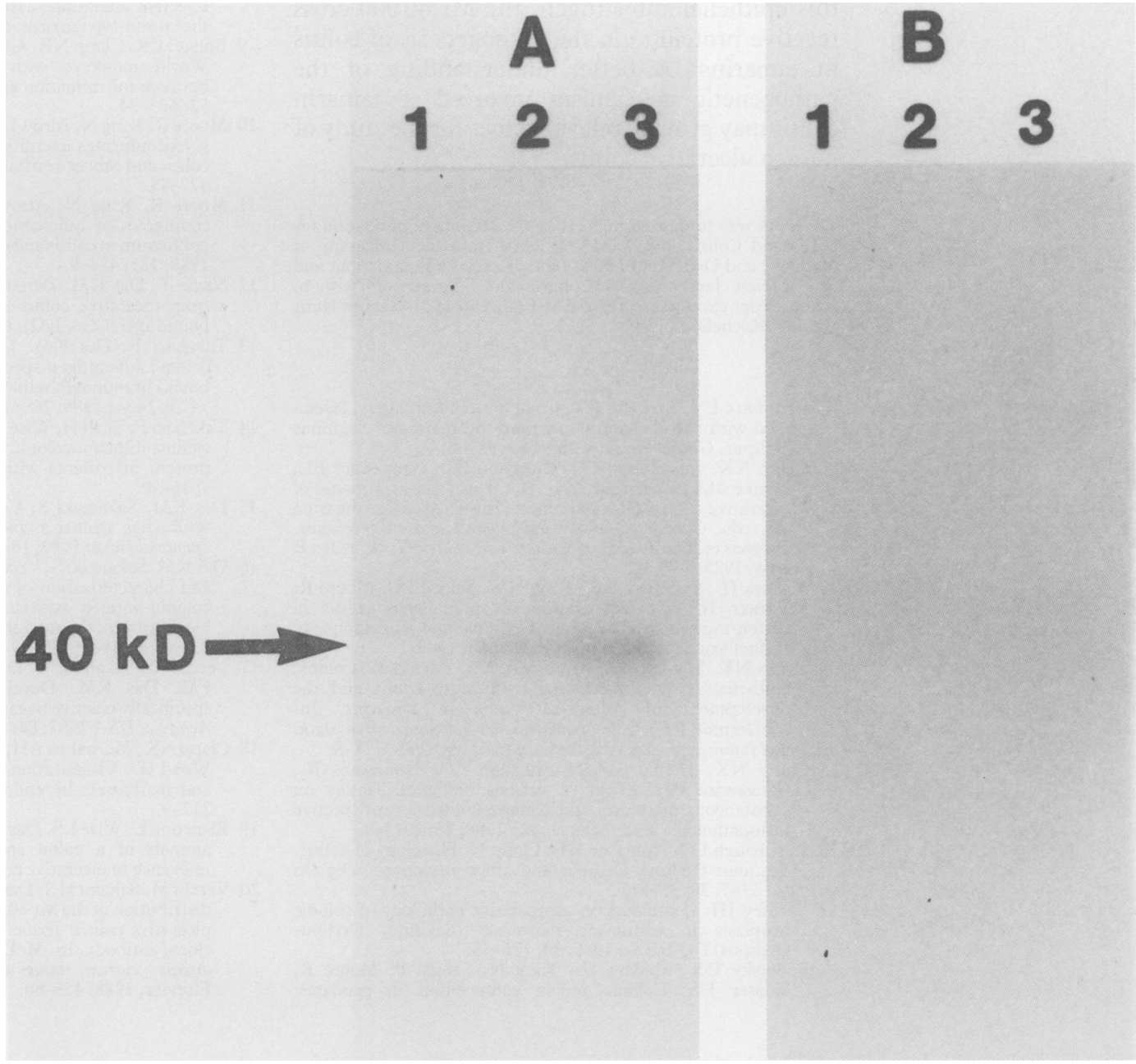

Figure 5: An autoradiograph from transblot experiments after exposure for 24 hours: phosphate buffered saline extracted proteins from tamarin small intestine (lanes $A_{1} B_{1}$ ), large intestine (lanes $A_{2} B_{2}$ ), and human colon (lanes $A_{3} B_{3}$ ) were probed with IgG eluted from the colon of a patient with ulcerative colitis $(C C A-I g G)$ (panel $A)$ and colon eluted IgG from a patient with Crohn's disease involving the colon (panel B). Immunoreactivity is observed at Mr 40000 areas in lanes 2 and 3 containing colon extracts from tamarin and human respectively. Tamarin small intestinal extract did not react. Eluted IgG from the colon specimen with Crohn's colitis also showed no reactivity.

experimental animals such as mice and rats was also observed only in colonic epithelium and not in the small intestinal mucosa. ${ }^{19}$ The immunoreactivity, as detected by the immunoperoxidase method, is localised to colonic epithelial cells, both in the crypts and along the luminal surface. This pattern of localisation of the protein in tamarin colon is similar to what is observed in humans. ${ }^{16}$ The localisation and the expression of the $\mathrm{Mr} 40000$ cross reactive epitope(s) were similar in normal colon specimens and in chronic colitis specimens from $S$ oedipus. The expression of the $\mathrm{Mr} 40000$ protein was also similar in specimens obtained from the right and left colon. This differs from what is observed in humans, where an increase of the immunoreactivity in the distal colon and rectum is seen. ${ }^{20}$

An important difference in the expression of Mr 40000 cross reactive epitopes was observed between $S$ oedipus versus $S$ fuscicollis and $C$ jacchus, the two species which do not develop colon cancer but may develop colitis.

The nature and similarity of the colitis in these two species compared with $S$ oedipus have been debated. ${ }^{59}$ It is intriguing that while each of the 36 colon specimens from all $S$ oedipus animals were reactive to $7 \mathrm{E}_{12} \mathrm{H}_{12}$, none of the 10 speci- mens from $S$ fuscicollis and eight of the 10 $C$ jacchus colon specimens did not react with $7 \mathrm{E}_{12} \mathrm{H}_{12}$. This finding shows a major difference in colonic mucosa among these species. Differences among the three species have also been observed by lectin histochemistry of colonic mucosa. ${ }^{10}$

Specimens from $S$ oedipus animals with acute colitis showed an appreciable reduction of immunoreactivity compared with specimens from normal colon or chronic colitis. This finding could be due to desctruction of the normal glandular epithelium associated with acute colitis. In addition, the cross reactive epitopes may also be blocked by the anti-Mr 40000 autoantibodies.

Eight of $10(80 \%)$ sera from cotton top tamarins with colitis (both acute and chronic) contained circulating antibody against the shared epitope on $\mathrm{Mr} 40000$ colonic epithelial protein reactive to $7 \mathrm{E}_{12} \mathrm{H}_{12}$ monoclonal antibody. These included four sera from autologous animals whose colon tissue was examined with their own sera. None of the sera from normal animals showed such immunoreactivity against tamarin colon tissue.

Future studies are needed to clarify the role of 
this epithelial autoantigen, the $\mathrm{Mr} 40000$ cross reactive protein(s) in the pathogenesis of colitis in tamarins. A better understanding of the pathogenetic mechanism involved in tamarin colitis may provide relevant clues for the study of human ulcerative colitis.

The work was supported in parts by the National Foundation for Ileitis and Colitis, by a research grant from the University or Medicine and Dentistry of New Jersey Research Foundation, and by the New Jersey Cancer Commission. The authors wish to and Mrs Rochelle Golub.

1 Chalifoux LV, Bronson RT. Colonic adenocarcinoma associated with chronic colitis in cotton-top marmoset Saguinus oedipus. Gastroenterology 1981; 80: 942-6.

2 Clapp NK, Lushbaugh CC, Humason GL, Gangaware BL Henke MA, McArthur AH. The marmoset as a model of ulcerative colitis and colon cancer. Ingalls M, Mastromarino $\mathrm{JF}$, eds. Carcinoma of the large bowel and its precursors. Prodess. Carcinoma of the large bowel and its precursors. Liss, 1985: 247-61.

3 Madara JL, Podolsky DK, King NW, Sehgal PU, Moore R, Winter HS. Characterization of spontaneous colitis in Winter HS. Characterization of spontaneous colitis in cotton-top tamarin (Saguinus Oedipus) and its response to

4 Clapp NK, Henke MA, McArthur AH, Carson R. Colonic epithelial changes associated with acute colitis and the development of colon carcinoma in tamarins. In: McDermott RP, ed. Inflammatory bowel disease: current status and future approach. Amsterdam: Elsevier, 1988: 713-8.

5 Clapp NK, Henke MA, Lushbaugh CC, Humason GL Gangaware BL. Effect of various biological factors on spontaneous marmoset and tamarin colitis: a retrospective histopathologic study. Dig Dis Sci 1988; 33: 1013-9.

6 Lushbaugh CC Humason GL, Clapp N. Histology of colitis. Saguinus Oedipus Oedipus and other marmosets. Dig Dis Saguinus Oedipus 1985 ; 30: 35-51S.

7 Yardley JH. Comments on comparative pathology of colonic neoplasia in cotton-top marmoset (Saguinus Oedipus neoplasia in cotton-top marmoset

8 Podolsky DK, Madara JL, King N, Sehgal P, Moore R, Winter HS. Colonic mucin composition in primates: selective alterations associated with spontaneous colitis in the cotton-top tamarin. Gastroenterology 1985; 88: 20-5.

9 Boland CR, Clapp NK. Glycoconjugates in the colons of New World monkeys with spontaneous colitis: association between inflammation and neoplasia. Gastroenterology 1987; 92: 625-34.

10 Moore R, King N, Alroy J. Characterization of colonic cellular glycoconjugates in colitis and cancer-prone tamarins versus colitis and cancer-resistant primates. Am f Pathol 1988; 131: 477-83.

11 Moore R, King N, Alroy J. Differences in cellular glycoconjugates of quiescent, inflamed and neoplastic colonic epithelium in colitis and cancer-prone tamarins. Am $\mathcal{F}$ Pathol 1988; 131: 484-9.

12 Nagai T, Das KM Detection of colonic antigen(s) in tissues from ulcerative colitis using purified colitis colon tissuebound IgG (CCA-IgG). Gastroenterology 1981; 81: 463-70.

13 Takahasi F, Das KM. Isolation and characterization of colonic autoantigen specifically recognized by colon tissuebound immunoglobulin $\mathrm{G}$ from idiopathic ulcerative colitis. f Clin Invest 1985; 76: 311-8.

14 Takahasi F, Shah H, Wise L, Das KM. Circulating antibodies against human colonic extract enriched with a $40 \mathrm{kD}$ protein in patients with ulcerative colitis. Gut 1990; 31: 1016-20.

15 Das KM, Sakamaki S, Vecchi M. Ulcerative colitis specific antibodies against a colonic epithelial $\mathrm{Mr} 40,000$ protein. Immunol Invest 1989; 18: 459-72.

16 Das KM, Sakamaki S, Vecchi M, Diamond B. The production and characterization of monoclonal antibodies to a human colonic antigen associated with ulcerative colitis: cellular localization of the antigen by using the monoclonal antibody. localization of the antigen by

17 Vecchi $M$, Sakamaki S, Diamond B, Novikoff $A B$, Novikof PM, Das KM. Development of monoclonal antibody specifically reactive to gastrointestinal goblet cells. Proc Nat Acad Sci USA 1987; 84: 3425-9.

18 Clapp NK, McArthur AH, Carson RL, Henke MA, Peck OC Wood JD. Visualization and biopsy of the colon in tamarin and marmosets by endoscopy. Lab Animal Sci 1987; 37: 217-9.

19 Biancone L, Wise LS, Das KM. The presence in experimental animals of a colon specific $\mathrm{Mr} 40000$ protein(s) with relevance to ulcerative colitis. Gut 1991; 32: 504-8.

20 Vecchi M, Sakamaki S, Das KM. Organ specificity and colonic distribution of the Mr 40,000 colonic protein associated with distribution of the $\mathrm{Mr} 40,000$ colonic protein associated with clonal antibody. In: McDermott RP, ed. Inflammatory bowel disease: current status and future approach. Amsterdam disease: current status
Elsevier, 1988: $455-60$.

更

(1) 